Reprinted with permission from: Geocarto International, March 1996. Vol. 11(1):81-89.

Published and copyrighted by: Geocarto International Centre, G.P.O. Box 4122, Hong Kong, People's Republic of China.

\title{
Mapping leafy spurge (Euphorbia esula) infestations using aerial photography and geographic information systems
}

\author{
G. L. ANDERSON ${ }^{\mathrm{a}}$, J. H. EVERITT ${ }^{\mathrm{a}}$, D. E. ESCOBAR ${ }^{\mathrm{a}}$, N. R. SPENCER ${ }^{\mathrm{b}}$, and \\ R. J. ANDRASCIK ${ }^{\mathrm{c}}$
}

${ }^{a}$ USDA, Agricultural Research Service, Remote Sensing Research Unit, 2413 East Highway 83, Weslaco, TX 78596 U.S.A. ${ }^{b}$ USDA, Agricultural Research Service, Northern Plains Soil and Water Research Laboratory, P.O. Box 1109, Sidney, MT 59270 U.S.A. ${ }^{c}$ USDI, National Park Service, Theodore Roosevelt National Park, P.O. Box 7, Medora, ND 58645 U.S.A.

\begin{abstract}
:
Leafy spurge is a troublesome weed on the northern Great Plains of the United States that chemicals and grazing management have not controlled, Remote sensing and geographic information system (GIS) technology have been used to detect and monitor numerous grassland related problems. The objectives of this study were to use both technologies to map and quantify the extent of leafy spurge within Theodore Roosevelt National Park and to provide information for managing the infestation. Analysis of the data indicated that 702 ha of the 18,680 ha park were infested by leafy spurge; however, leafy spurge populations occurring under dense woody canopies, in deep stream channels, and on steep slopes were not always detected. Infestations were especially dense in the western and southeast portions of the park. Most infestations were restricted to riparian zones and smaller drainage channels. Leafy spurge infestations decreased exponentially as distance from stream channels increased $\left(r^{2}=0.98\right)$. The significant association of leafy spurge with drainage channels suggests that the weed might be effectively managed on a watershed sub-basin level. The joint use of GIS and remote sensing proved to be a powerful combination of tools, which provided previously unavailable information about the extent and spatial dynamics of leafy spurge within the park. The results of this study will contribute to the development of a comprehensive leafy spurge management plan for Theodore Roosevelt National Park (South Unit).
\end{abstract}




\section{Introduction}

Leafy spurge (Euphorbia esula L.) is a deep-rooted, perennial weed with erect stems 40 to $80 \mathrm{~cm}$ tall (Stevens, 1963). The weed reproduces by both vegetative buds and the production of large quantities of seeds. A native of Eurasia, leafy spurge was first reported in the state of Massachusetts in 1827 (Noble et al., 1979). Leafy spurge now occurs abundantly on the Northern Great Plains of the United States and the Prairie Provinces of Canada where it often forms stands dense enough to displace native plants and restrict cattle grazing (Rees and Spencer, 1991).

Various control methods have been tried. Long term chemical control of leafy spurge has generally proven ineffective and expensive because of the extensive area infested and the number of repeat applications needed to destroy new plants germinating from a seed bank that remains viable for many years (Lym and Messersmith, 1983; Gy1ling and Arnold, 1985; Lym and Messersmith, 1985; Messersmith, 1979; Alley and Messersmith, 1985; Harvey et al., 1988). Grazing by sheep has reduced the density and limited the spread of leafy spurge, but does not eradicate the weed (Landgraf et al., 1984; Fay, 1991). Control with pathogens (Quimby et al., 1991) and insects (Anonymous, 1989; Rees and Spencer, 1991) is currently being evaluated.

Determining the extent and distribution of weed populations on rangelands is often difficult because of the expanse and inaccessibility of these areas. The value of using remote sensing information for rangeland assessment is well established (Tueller 1982; Carneggie et al., 1983). Remote sensing offers rapid acquisition of data and at costs lower than ground surveys (Tueller; 1982; Everitt et al., 1992). Aerial photography and videography have both proven useful for detecting the presence and distribution of many rangeland plants (Driscoll and Coleman, 1974; Gausman et al., 1977; Carneggie et al., 1983; Everitt et al., 1987, 1992, 1993). Observations timed to take advantage of specific phenological stages have helped to distinguish plant species of interest from others present (Driscoll and Coleman, 1974; Everitt and Villarreal, 1987; Everitt and Deloach, 1990). Leafy spurge produces yellow bracts in late May or early June that give the plant a conspicuous yellow-green appearance (Lacey et al., 1985). We hypothesized that leafy spurge might be distinguishable on aerial imagery during this phenological stage.

Geographic information system (GIS) and remote sensing technology have been integrated for a variety of natural resource applications (Graetz et al., 1983; Eidenshink et al., 1988; Myhre, 1992; Richardson et al., 1993; Anderson et al., 1993b), including mapping the distribution of noxious weeds (Dewey et al., 1991; Anderson et al., 1993a; Everitt et al., 1994). Remote observations in geo-referenced formats help to assess the extent of infestations, develop management strategies, and evaluate control measures on noxious plant populations.

Leafy spurge was first reported in Theodore Roosevelt National Park in the late 1960. In 1970 an estimated 13 ha of the park were infested. The infestation increased to 162 ha between 1975 and 1983, and was conservatively estimated as 283 ha in 1986. The objectives of this study were (1) to map and quantify the extent and distribution of leafy spurge within Theodore Roosevelt National Park (South Unit) during the summer of 1993, and (2) to provide information for managing the infestation. 


\section{Materials and methods}

This study was conducted on the south unit of Theodore Roosevelt National Park, near Medora, North Dakota. The south unit encompasses 18,680 ha of native mid-grass prairie. Geologically, the park is comprised of clay and sandstone layers deposited in the Williston basin during the late Paleozoic period (Levin, 1978). The entire area was uplifted by the formation of the Black Hills and subsequently highly eroded by glacial meltwaters released at the end of the last ice age. These geologic events produced the rugged clay buttes, limited topsoil, and sandstone outcroppings that characterize the North Dakota Badlands.

Aerial photography was chosen for this project because of the high resolution of film. Imagery was acquired using a large format camera $(23$ by $23 \mathrm{~cm})$ with a $305-\mathrm{mm}$ lens. Conventional color film was used and the aperture setting of the camera was f11 at 1/250 s. Photographs were taken from 0900 to 1100 hours on June 19, 1993, at a scale of 1:10,000. Over 140 photographs were taken at regular intervals, based on coordinates from a non-differential global positioning system (GPS) mounted in the cabin of the aircraft. Photographs were taken with a $40 \%$ end lap and a $30 \%$ side lap to ensure complete coverage.

Mapping leafy spurge within the park was a multistep procedure. First, all aerial photographs were examined to determine if leafy spurge was visible within the scene. Photographs showing spurge were covered with a clear vellum to protect the original print, and the perimeters of the leafy spurge populations were drawn on the overlay. Tie points that geo-referenced features on the photograph with coordinates from USGS 7.5 minute Orthophoto quadrangle maps were also identified and marked on each photograph. Terrain features such as butte tops, clay outcroppings, and stream intersections were used as tie points because each photograph contained few identifiable standard map features. Coordinates for the tie points were obtained from the orthophoto maps by digitizing each position and recording it in a GIS. The corresponding tie points on the photographs and the perimeter of each leafy spurge population were also digitized and recorded in the GIS. The registration procedure used the common tie points on the photographs and orthophoto quadrangle maps to register the leafy spurge polygons to a standard North American Datum (NAD), 1983, Universal Transverse Mercator (UTM), Zone 13, coordinate system. A minimum of 10 tie points, scattered across the image, were selected on each aerial photograph.

Photographs were examined for leafy spurge two times. Photo interpreters at the Remote Sensing Research Unit (RSRU) in Weslaco, TX conducted the first evaluation based primarily on the spectral responses displayed in the photography. Park managers subsequently re-evaluated each photograph and, based on their historical knowledge of existing leafy spurge populations, added areas that were not at first apparent on the photographs.

Map features such as roads, trails, hydrography and the park boundary were digitized from a USGS, 1:24000 scale topographic map converted to a NAD-1983 coordinate base and combined with the leafy spurge polygons in a raster GIS. Each cell on the GIS database was $5 \mathrm{~m}$ by $5 \mathrm{~m}$. Digital elevation data (USGS-DEM, $30 \mathrm{~m}$ by $30 \mathrm{~m}$ horizontal and 5 $\mathrm{m}$ vertical resolution) were acquired for the five-7.5 minute quadrangle maps that cover 
the park, and joined together. The DEM data were used to develop slope, aspect, stream channel, and watershed basin maps. Stream channel data were used to develop a proximity to channel map for the entire park. A stream channel proximity map indicates the distance of all points in the park from the closest stream channel. These data were subsequently divided into $10 \mathrm{~m}$ intervals and the total land area, and area covered by leafy spurge within each band determined. Digital map products and statistics presented in this report were produced using software subroutines contained in the Geographical Resources Analysis Support System (GRASS) ${ }^{1}$ GIS.

Data needed for accuracy assessment were collected during the summer of 1994. A GPS system was used to assign UTM coordinates to observations collected along, transects running through the Little Missouri River and Paddock Creek drainage areas. Observations were made every 50 meters along the transect with the observer recording the OPS location and the presence or absence of leafy spurge. The location estimates were latter differentially corrected to determine the location of each observation with an accuracy of plus or minus one meter. These data were to be used in a standard error matrix to evaluate map accuracy (Lillesand and Kiefer, 1987). Estimated map accuracy is defined as the percentage of ground observations correctly identified on the map. Map error is broken down into the percentage of observations that were leafy spurge and not included as spurge on the map (errors of omission); and the percentage of observations that were not leafy spurge and designated as spurge on the map (errors of commission).

\section{Results}

Analysis of the digital park data derived from a 1:24000 scale map indicated that the south unit of Theodore Roosevelt National Park encompassed 18,676 ha of the North Dakota Badlands. This estimate compares favorably with the official 18,680 ha extent for the south unit. Leafy spurge area estimates, derived from the aerial photography by RSRU personnel, accounted for 550 ha of the park. Subsequent reevaluation of the imagery by park managers increased the leafy spurge area estimate to 702 ha, or $4 \%$, of the park area (Fig. 1). Areas added by park officials were stands difficult to distinguish on the photography and small isolated populations missed during the initial evaluation. The addition of 152 ha to the original estimate highlights the need to include personnel familiar with the area and the specific problem in the photo interpretive process.

The densest infestations of leafy spurge within the park occurred in the Petrified Forest Plateau region, Knutson Creek, and the floodplain of the Little Missouri River. Smallscattered populations of spurge were evident throughout most major park drainages and another large population of spurge occurred on the upper end of the Paddock Creek drainage basin (Fig. 1). Most of the infestation appeared to be restricted to drainage channels, creek bottoms, and river bottoms. Figure 2 emphasizes the non-random distribution of leafy spurge within the park. The curvilinear relationship:

$$
\text { Area }=93.88 \mathrm{e}^{-1.01381782 \mathrm{~d}} \text {, }
$$

\footnotetext{
${ }^{1}$ GRASS is a product of the U.S. Army Corps of Engineers Construction of Engineers Construction Engineering Research Laboratories (USACERL) in Champaign, IL.
} 
where area $=$ the total area infested by leafy spurge and $d=$ the distance from a drainage channel in 10 meter increments, accounts for 98 percent $\left(r^{2}=0.98\right)$ of the variance found in the data. Leafy spurge was not closely associated with other topographic features. Spurge seemed to have a slight affinity for northeasterly aspects and gentler slopes; however, substantial spurge populations existed over all conditions (Tables 1 and 2).

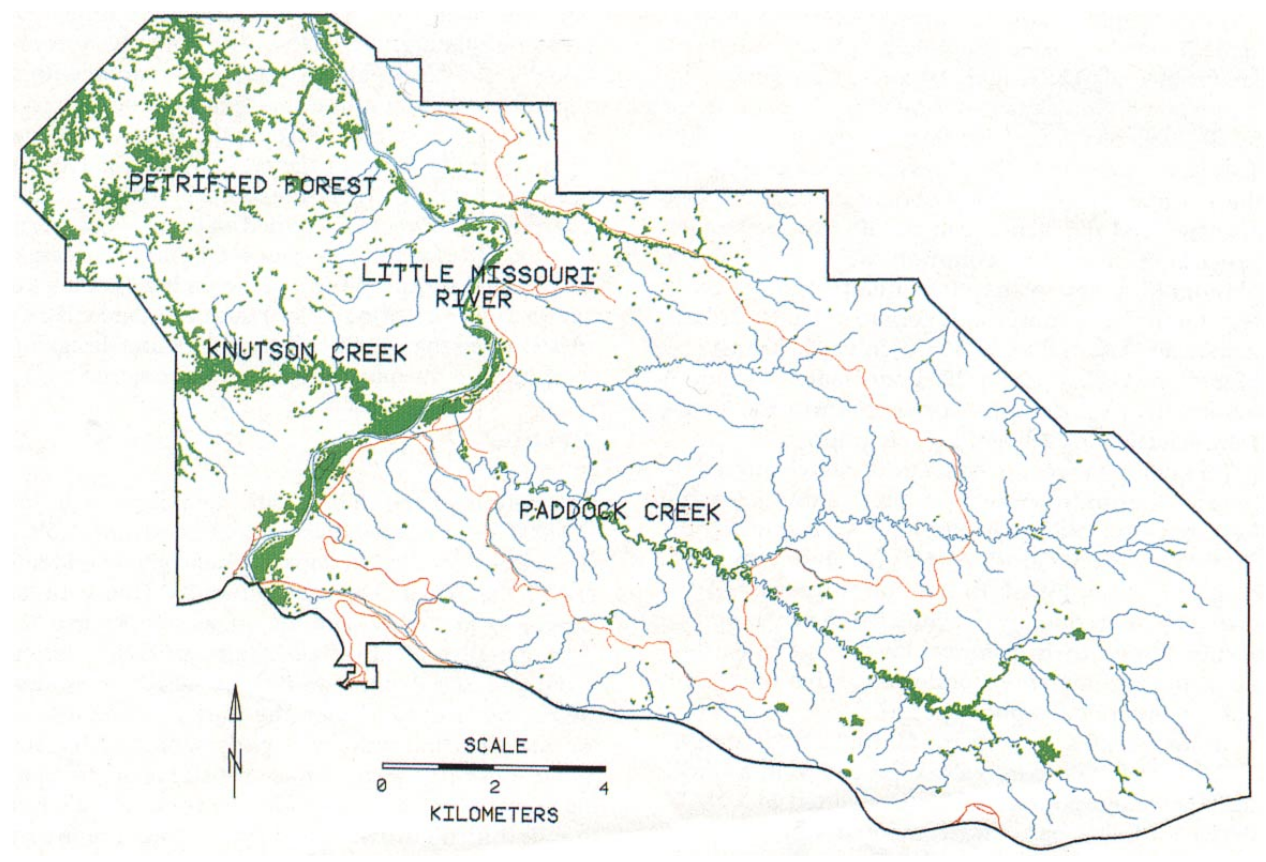

Figure 1 Map of leafy spurge infestations, shown in yellow, within Theodore Roosevelt National Park (South unit).

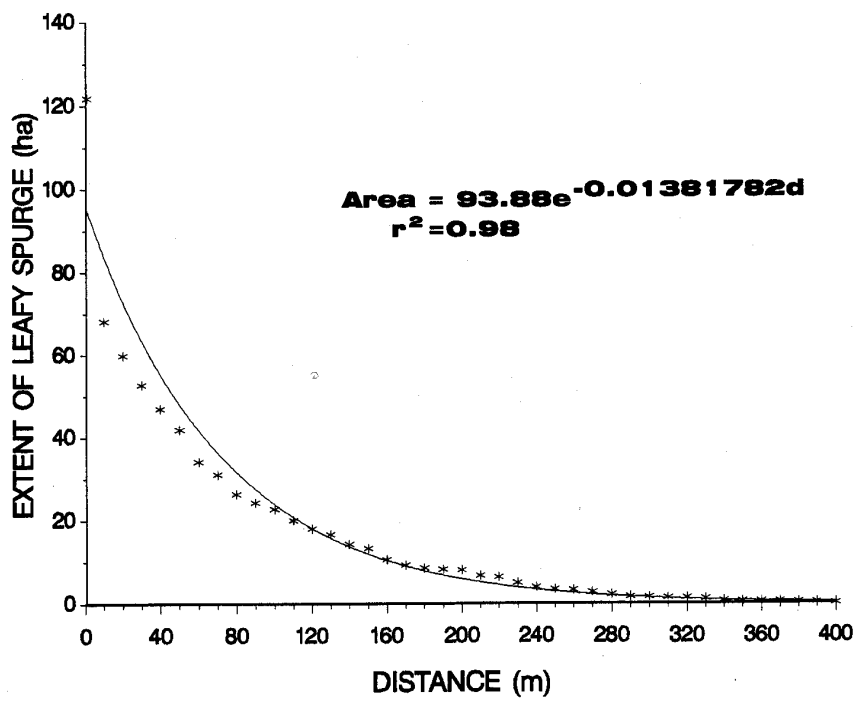

Figure 2 Relation between area inhabited by leafy spurge and the distance of the stands from a drainage channel. 
Table 1 The association of slope and leafy spurge in Theodore Roosevelt National Park (South Unit).

\begin{tabular}{cc}
\hline Slope (\%) & Area (ha) \\
\hline $0-2$ & 128.3 \\
$3-5$ & 183.8 \\
$6-10$ & 86.7 \\
$11-15$ & 105.3 \\
$16-20$ & 84.1 \\
$21-25$ & 52.1 \\
$>26$ & 51.1 \\
Undetermined & 10.6 \\
\hline
\end{tabular}

Table 2 The association of aspect and leafy spurge in Theodore Roosevelt National (South Unit).

\begin{tabular}{lc}
\hline Aspect & Area (ha) \\
\hline ESE & 80.0 \\
SSE & 74.0 \\
SSW & 93.7 \\
WSW & 60.6 \\
WNW & 70.7 \\
NNW & 76.1 \\
NNE & 103.4 \\
ENE & 119.5 \\
Undetermined & 24.0 \\
\hline
\end{tabular}

Sixteen major watershed sub-basins were developed for the park from USGS-DEM data (Fig. 3). The GIS watershed routine delineated watershed boundaries well in the steeper portions of the park, but it did not do as well along the Little Missouri River floodplain where the slope values were low. Several sub-basins were combined into four large floodplain basins (Basins 13,14, 15, 16) to compensate for this problem. Leafy spurge was found in 15 of the 16 watershed basins (Table 3). Sub-basins 9 and 10, in the northwest portion of the park, contained 355 ha (over 50\%) of the leafy spurge in the park and sub-basin 12 , in the southeast portion of the park, appeared to be free of leafy spurge.

Figure 4, groups the data from Table 3 into areas of heavy, moderate, light, and no leafy spurge infestations. Heavy infestations included basins with greater than 5 percent of the land area covered by leafy spurge. Moderate, light, and no leafy spurge categories were assigned to basins with greater than one but less than or equal to five, greater than zero but less than or equal to one, and zero percent coverage respectively (Table 3 ). Figure 4 depicts the heavy infestation of the major drainages of the park (Knutson Creek, Paddock Creek, and the Little Missouri River), the large portion of the park that is being threatened by leafy spurge, and, conversely the small amount of land that has not yet been infested.

Quantitative assessment of the leafy spurge map using differentially corrected GPS data was not possible. Apparently a problem occurred during the differential correction 
process that made the corrected GPS data files unreadable. Unfortunately, uncorrected GPS data were deleted from the system before the problem was identified. Qualitative assessment, however, indicated that not all leafy spurge in the park was detected. Leafy spurge was not detected under dense riparian forest canopies or woody draws. Interpreters also had difficulty-detecting spurge in deep stream channels and on steep slopes. Contributing factors included: limited visibility, shadows, reduced plant height in conjunction with sparse plant density, and limited bract production

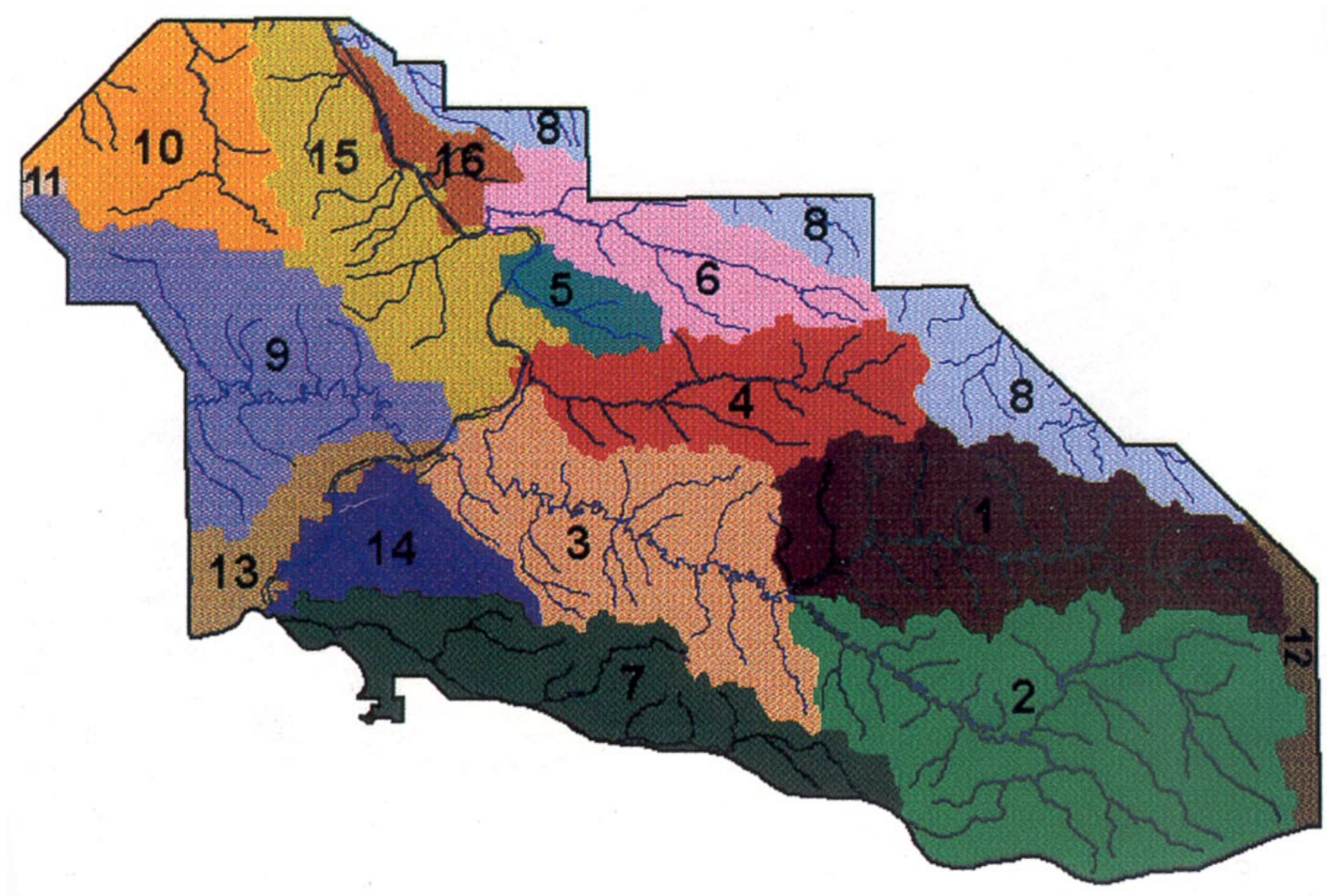

Figure 3. Watershed sub-basin map developed from the USGS Digital Elevation Model (DEM) data. 
Table 3. The extent of leafy spurge populations in each of 16 watershed sub-basins within Theodore Roosevelt National Park (South Unit).

\begin{tabular}{cccc}
\hline Basin & Total Area (ha) & Spurge (ha) & $\%$ \\
\hline 1 & 2089 & 3.2 & 0.2 \\
2 & 3170 & 60.0 & 1.9 \\
3 & 1919 & 36.0 & 1.9 \\
4 & 1258 & 5.9 & 0.5 \\
5 & 297 & 5.3 & 1.8 \\
6 & 1009 & 25.9 & 2.6 \\
7 & 1506 & 15.7 & 1.1 \\
8 & 1272 & 7.2 & 0.6 \\
9 & 1703 & 169.2 & 9.9 \\
10 & 1143 & 185.4 & 16.2 \\
11 & 31 & 4.4 & 14.2 \\
12 & 243 & 0.0 & 0.0 \\
13 & 473 & 44.3 & 9.4 \\
14 & 624 & 50.1 & 8.0 \\
15 & 1595 & 76.8 & 4.8 \\
16 & 336 & 12.4 & 3.7 \\
\hline
\end{tabular}

\section{Discussion}

Normal color aerial photography was useful in mapping leafy spurge infestations in relatively open areas of Theodore Roosevelt National Park. However, remote sensing must be combined with ground surveys in areas where visibility is limited or where small sparse populations of spurge occur. The methodology used in this study was not an effective approach for detecting new infestations comprised of a few small plants, but it was effective in detecting the yellow green signature of well-developed stands of leafy spurge as small as 3-5 feet in diameter.

The non-random distribution of leafy spurge indicates that some factor(s) increase the likelihood of stand establishment near drainage channels. One contributing factor could be that leafy spurge populations are distributed in direct proportion to the amount of total land area present at varying distances from drainage channels, An analysis of the total surface area of the park demonstrates that for distances between 0 and $360 \mathrm{~m}$ from a drainage channel, the amount of surface area decreases linearly (Fig. 5). Therefore, the distribution of the weed is not merely a reflection of the amount of available land area. 


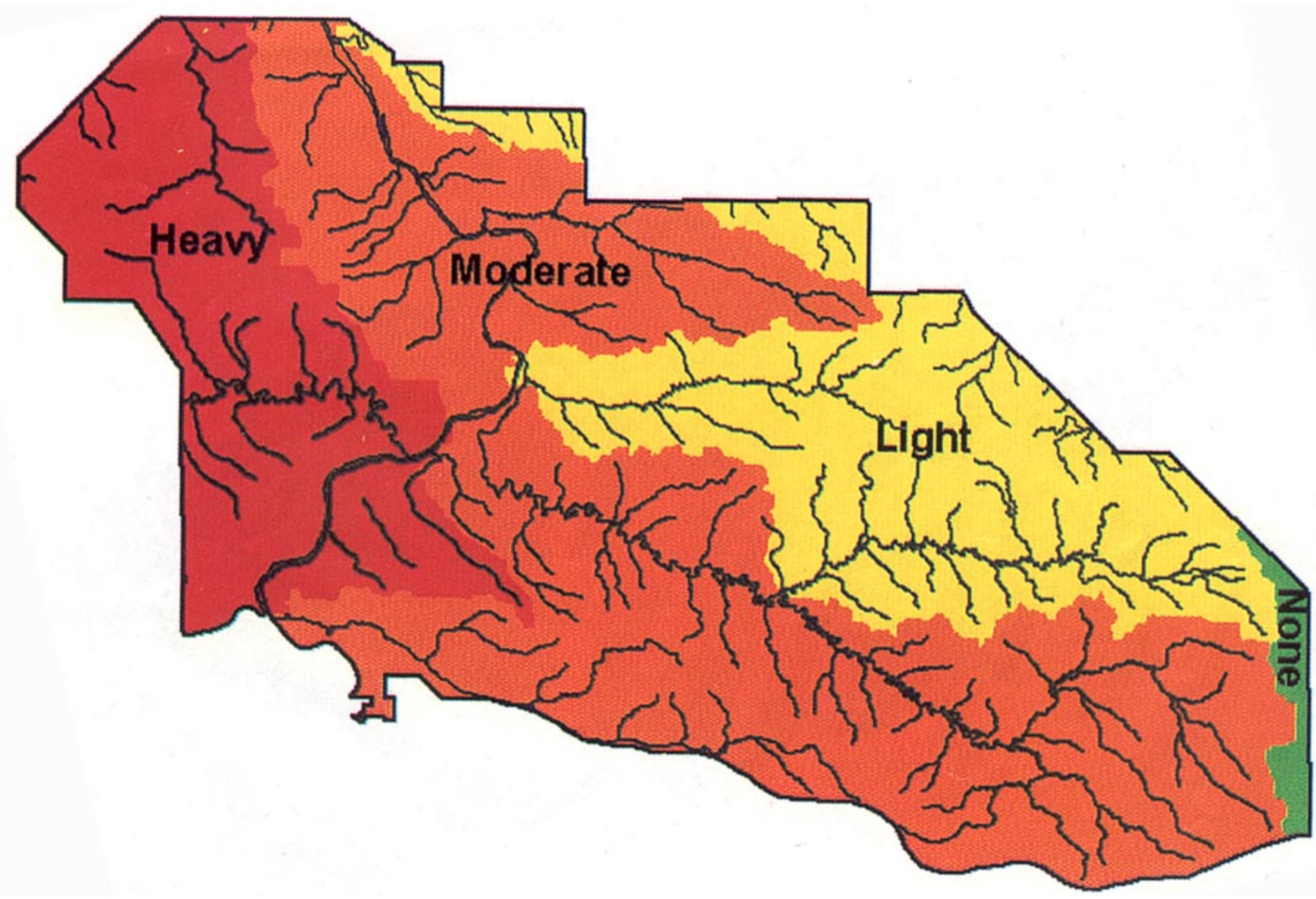

Figure 4. General breakdown of leafy spurge infestation by watershed sub-basin. Heavy $(>5 \%$, red), moderate ( $>1$ but $<=5 \%$, blue), light $(>0$ but $<=1 \%$, yellow), and none infested areas (green).

The observed distribution of leafy spurge could be a function of time, given the primary mode of seed introduction into an area is by surface water movement (accounting for the majority of the stands existing close to a drainage channel) and lateral movement away from a drainage channel is by seedpod dispersal (which requires time for stand establishment, seed production, and dissemination). If the distribution is a function of time, the curvilinear distribution shown in figure 2 should begin to flatten and approach the total land surface distribution (Fig. 5) as the spurge population's advance further from the drainage channels. This hypothesis needs further investigation. However, the large isolated stands of leafy spurge found on the upper end of the Paddock Creek drainage basin indicate that other modes of seed introduction (wind, man, wildlife, or domestic animals) are important. Seed deposition by modes of movement other than water and pod dispersal could be selective for drainage channel areas, however, the expectation is that the distribution would be much more random. The distribution of spurge within the park is so significantly associated with the drainage channels, that factors such as soil moisture must be important influences on the success of leafy spurge establishment. In any case, the data indicate a predictable pattern of stand establishment that park managers can use to combat the spread of leafy spurge. 


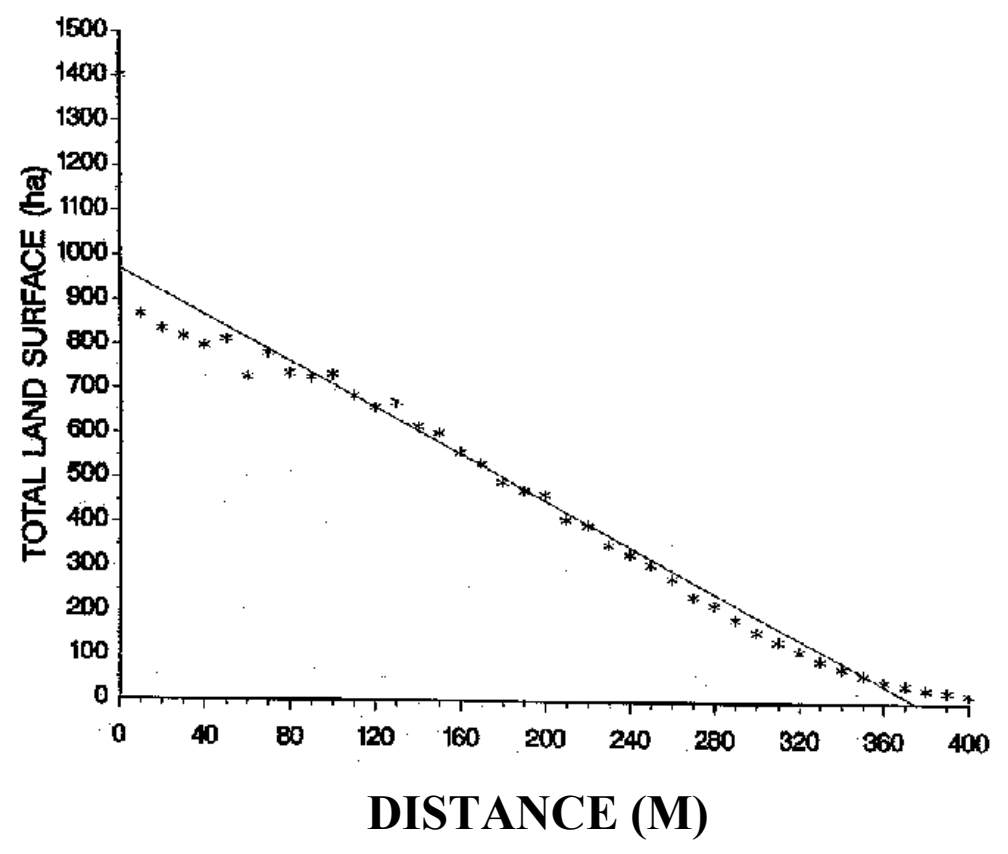

Figure 5. Relation between total land area and distance from a drainage channel.

The significant association of leafy spurge populations with drainage channels suggests that the weed might be effectively managed on a watershed basin or sub-basin level. In particular, the limited resources of the park could be partitioned to prevent the spread of the weed to uncontaminated areas, eliminating small new infestations, and retarding the advance of the larger, more established leafy spurge populations.

\section{Conclusions}

The GIS was a good base for incorporating the polygons of leafy spurge identified on aerial photographs. Distortions in the photography that were removed by using the GIS to register the data to the USGS orthophoto maps aided in accurately estimating the size of the spurge infestations. The GIS also made it possible to combine the leafy spurge data with other existing data (map features or digital elevation data) and create new information (watershed basin, stream, slope, and aspect maps) for a more in-depth analysis of the problem. The joint use of GIS and remote sensing proved to be a powerful combination of tools that provided previously unavailable information about the extent and spatial dynamics of leafy spurge within the park. The results of this study will contribute to the development of a comprehensive leafy spurge management plan for the south unit of Theodore Roosevelt National Park.

\section{Acknowledgments}

The authors thank M. R. Davis, W. Swanson, and I. Cavazos for their time and assistance in obtaining the photography and creating the GIS database. Thanks are also extended to S.R. Hager, J.R. Muller, and K.J. Privratshy for their efforts in re-evaluating the 
aerial photography and providing ground observations of leafy spurge infestations within the park.

\section{Literature Cited}

Alley, H. P. and Messersmith, C. G. 1985. Chemical control of leafy spurge. Pages 65-79 in: A. K. Watson (ed.), Leafy Spurge. Weed Sci. Soc. Am., Champaign, IL.

Anderson, G. L., Everitt, J. H., Richardson, A. J., and Escobar, D. E. 1993a. Using satellite data to map false broomweed (Ericameria austrotexana) infestations on South Texas rangelands. Weed Tech. 7:865871

Anderson, G. L., Hanson, J. D., and Haas, R. H. 1993b. Evaluating LANDSAT thematic mapper derived vegetation indices for estimating aboveground biomass on semi-arid rangelands. Remote Sensing of Environment 45:165-175.

Anonymous. 1989. Biological control of leafy spurge. United States Department of Agriculture, Animal and Plant Health Inspection Service. Progress Aid No. 1435. 11 p.

Carneggie, D. M., Schrumpf, B. J., and Mouat D. M. 1983. Rangeland applications. pages 2325-2384 in R. N. Colwell (ed.), Manual of Remote Sensing. Vol. 2. Am. Soc. Photogrammetry and Remote Sensing, Falls Church, VA.

Dewey, S. A., Price, K. P., and Ramsey, D. 1991. Satellite remote sensing to predict potential distribution of Dyers wood (Isatis tinctoria). Weed Tech. 5:479-484.

Driscoll, R. S. and Coleman, M. D. 1974. Color for shrubs. Photogramm. Eng. 40:451-459.

Eidenshink, J. C., Haas, R. H., Zokaites, D. M., Ohlen, D. 0., and Gallo, K. P. 1988. Integration of remote sensing and GIS technology to monitor fire danger in the Northern Great Plains. U. S. Geological Survey Contract 14-08-000122521. 13p.

Everitt, J. H., Alaniz, M. A., Escobar, D. E., and Davis, M. R. 1992. Using remote sensing to distinguish Common (Isocoma coronopifolia) and Drummond goldenweed (Isocoma drummondii). Weed Sci. 40:621-628.

Everitt, J. H. and Deloach, C. J. 1990. Remote sensing of Chinese tamarisk (Tamarix chinensis) and associated vegetation. Weed Sci. 38:273-278.

Everitt, J. H., Escobar, D.E., Villarreal, R., Alaniz, M. A., and Davis, M. R. 1993. Canopy light reflectance and remote sensing of shin oak Quercus havardii) and associated vegetation. Weed Sci. 41 :291 -297.

Everitt, J. H., Richerson, J. V., Alaniz, M. A., Escobar, D. E., Villarreal, R., and Davis, M. R. 1994. Light reflectance characteristics and remote sensing of Big Bend loco (Astragalus mollissimus var. earlei) and Wooton loco (Astragalus wootonii). Weed Sci. 42:(115-122).

Everitt, J. H., Pettit, R. D., and Alaniz, M. A. 1987. Remote sensing of broom snakeweed (Gutierrezia sarothrae) and spiny aster (Aster spinosus). Weed Sci. 35:295-302.

Everitt, J. H. and Villarreal, R. 1987. Detecting huisache Acacia farnesiana) and Mexican paloverde (Parkisonia aculeata) by aerial photography. Weed Sci. 35:427-432.

Fay, P. K. 1991. Controlling leafy spurge with grazing animals. Pages 193-199 in L. F. James, J. 0. Evans, M. H. Ralphs and R. D. Child (ed.), Noxious Range Weeds. Western Press, Boulder, CO.

Gausman, H. W., Menges, R. M., Escobar, D. E., Everitt, J. H., and Bowen, R. L. 1977. Pubescence affects spectra and imagery of silverleaf sunflower (Helianthus argophyllus). Weed Sci. 25:437-440.

Graetz, R. D., Pech, R. P., Gentle, M. R., and O'Callaghan, J. F. 1983. The application of LANDSAT image data to rangeland assessment and monitoring: The development and demonstration of a land image-based resource information system (LIBRIS). J. of Arid Environments 10:53-80.

Gylling, S. R. and Arnold. W. E. 1985. Efficacy and economics of leafy spurge (Euphorbia esula) control on pasture. Weed Sci. 33:381-385.

Harvey, S. J., Nowierski, R. M., Mahlberg, P. G., and Story, J. E. 1988. Taxonomic evaluation of leaf and latex variability of leafy spurge (Euphorbia spp.) for Montana and European accessions. Weed Sci. 36:726-733. 
Lacey, C. A., Fay, P. K., Lym, R. G., Messersmith, C. G., Maxwell, B., and Alley, H. P. 1985. The distribution, biology and control of leafy spurge. Circular 309. Cooperative Extension Service, Montana State University, Bozeman, MT. 15 p.

Landgraf, B. K., Fay, P. K., and Havstad, K.- M. 1984. Utilization of leafy spurge (Euphorbia esula) by sheep. Weed Sci. 32:348-352.

Levin, H. L. 1978. The Late Paleozoic. in: The Earth Through Time. W.B. Saunders Company, Philadelphia 530 p.

Lillesand, T. M., and Kiefer, R.W. 1987. Remote Sensing and Image Interpretation, (2nd Ed.), John Wiley \& Sons, New York.

Lym, R. G. and Messersmith, C. G, 1983. Control of leafy spurge with herbicides. North Dakota Farm Res. Bull. 40(5):16-19, 26.

Lym, R. G. and Messersmith, C. G. 1985. Leafy spurge control with herbicides in North Dakota: 20-year summary. J. Range Manage. 38:149-154.

Messersmith, C. G. 1979. Leafy spurge chemical control. Page 78. Proc. Leafy Spurge Symp. North Dakota Coop. Ext. Serv., Fargo. 84 pp.

Myhre, R. J. 1992. Use of color airborne videography in the U. S. Forest Service. Pages 145-152 in: Proc. Resource Technology 92 Sympos. Amer. Soc. Photogrammetry and Remote Sensing, Bethesda, MD.

Noble, D. L., Dunn, P. H., and Andres, L. A. 1979. The leafy spurge problem. Pages 8-15 in: Proc. Leafy Spurge Symposium. Bismarck, ND. June 26 and 27.

Quimby, P. C., Bruckart, W. L., Deloach, C. J., Knutson, L., and Ralphs M. H. 1991. Biological control of rangeland weeds. Pages 85-102 in: L. F. James, J. 0. Evans, M. H. Ralphs, and R. D. Child (ed.), Noxious Range-Weeds. Western Press, Boulder, CO.

Rees, N. E. and Spencer, N. R. 1991, Biological control of leafy spurge. Pages 182-192 in: L. F. James, J. 0. Evans, M. H. Ralphs, and R. D. Child,(ed.), Noxious Range Weeds. Westview Press, Boulder, CO.

Richardson, A. J., Summy, K. R., Davis, M.R., Gomez, A. and Williams, D. W. 1993. The use of 1990 Tiger/Line Census files for monitoring the Rio Grande Valley cotton stalk destruction program. Proc. Application of Advanced Information Technologies Sympos. pp. 231-239.

Stevens, O. A. 1963. Handbook of North Dakota plants. North Dakota Institute of Regional Studies. Page 197. Cushing-Malloy, Inc. Ann Arbor, MI. 324 p.

Trammell, M. A. 1994. Exotic plants of Theodore Roosevelt National Park: extent, distribution and ecological impact. M.S. Thesis, University of South Dakota, Vermillion. 174 PP.

Tueller, P. T. 1982. Remote sensing for range management. Pages 125-140 in: C. J. Johansen and J. L. Sanders (ed.), Remote Sensing for Resource Management. Soil Conserv, Soc. Am., Ankeny, IO.

Wallace, N. M., Leithch, J. A., and Leistritz, F. L. 1992. Economic impact of leafy spurge on North Dakota. North Dakota Farm Research Vol. 49, No. 5. 